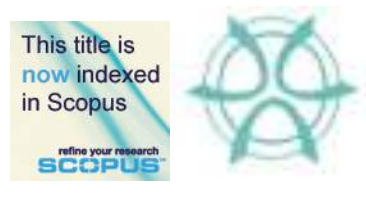

PLANNING MALAYSIA:

Journal of the Malaysian Institute of Planners

SPECIAL ISSUE IV (2016), Page 121 - 134

\title{
THE IMPACT OF ISKANDAR MALAYSIA DEVELOPMENT ON URBAN AMENITIES
}

\author{
Muhammad Rafeq Razak ${ }^{1}$, Foziah Johar ${ }^{2}$ \& Rabiatul Adawiyah Abd Khalil \\ ${ }^{1,2,3}$ Faculty of Built Environment \\ UNIVERSITI TEKNOLOGI MALAYSIA
}

\begin{abstract}
For major cities in Malaysia, globalized urban images are enthusiastically pursued by urban policy and explicitly depicted as a blueprint for a civilized city life. These developments have implications to physical and socio-economic developments as well as cultural aspects of cities in Malaysia. This is especially true for Iskandar Malaysia (IM), a new corridor development envisioned to be a "sustainable conurbation of international standingee. The whole initiatives targeted an enormous increase in socio-economic development indicators such as populations (222\%), workforce (233\%), and per-capita GDP $(210 \%)$ during a 20-year period of 2005-2025. Since its establishment in 2006, Iskandar Malaysia has witnessed wide spread urban renewal and new urban/suburban projects which resulted in distinct physical and socio-economic changes. One of the challenges to urban consumption is the provision and allocation of amenities to people within the region. A main concern of this paper is to identify the impact of Iskandar Malaysia development on urban amenities distribution. The 2000 and 2010 census data will be explored using GIS to explain the spatial distribution of health, education and safety amenities. This information will be matched with the residential distribution to determine amenities' location, distribution and accessibility.
\end{abstract}

Keyword: Gentrification, Iskandar Malaysia, globalization, socioeconomic implication

\section{INTRODUCTION}

Since independence Malaysia has built on the initial stock of infrastructure and all categories of infrastructure have since expanded manifold and facilities have also been modernised. The development of infrastructure has required very large investments. The infrastructure sector has received the largest share of public sector development expenditure in every one of the Malaysia Plans. However from the early 1990s because of resource constraints faced by the public sector, among other reasons, the Government has encouraged and facilitated private sector participation in infrastructure development. Three aspects to the Malaysian economy continue to have an important influence on infrastructure development in the country, these being the growth performance of the economy, the physical make-up of the country and the socio-economic disparities between the different parts of the country. These three matters have had to be taken into consideration in the formulation of infrastructure policies and allocation of resources for infrastructure development (Naidu, G. (2008), 'Infrastructure Development in Malaysia', 
Muhammad Rafeq Razak, Foziah Johar \& Rabiatul Adawiyah Abd Khalil

The Impact of Iskandar Malaysia Development on Urban Amenities

in Kumar, N. (ed.),International Infrastructure Development in East Asia - Towards Balanced Regional Development and Integration, ERIA Research Project Report 2007-2, Chiba: IDE-JETRO, pp.204-227.)

Over the last decade, globalization and economic competiveness have brought greater pressure on Malaysia particularly in providing high impact infrastructures and facilities to support rapid urbanization and industrialization process. Cities like Kuala Lumpur and Penang have undergone massive physical and social demographic changes similar to other major metropolitan center in Southeast Asian countries (Hogan et. al., 2012; Morshidi, 2000; Nasongkhla and Sintusingha, 2012). Iskandar Malaysia launched in 2006 was the second development region to be established after Greater Kuala Lumpur to strengthen the southern region economic condition (Foziah \& Adawiyah, 2014). This region was designed to become an international sustainable metropolis. The rapid urban growth in Iskandar Malaysia however bring multiple challenges in managing the region which include providing adequate urban services and amenities, addressing urban poverty, providing infrastructure, establishing efficient governance and revitalizing slum neighborhood ( Newton, 2001). The tremendous pressure brought by globalization and urbanization caused urban areas to expand as urban population grew dramatically. The region required a high impact infrastructure and utilities as engine to stimulate the growth and meet the global market. According to Noraniza et al.,(2011), development of infrastructure and facilities played a major role in improving the economy and quality of life. It is also argued that a key element in the transition to more urbanised environments is related to the extent to which urban amenities have a role in resident perceptions of quality of quality of urban life (Allen, 2015).

Amenities as claimed by Machado et al., (2013) consist of public and private goods and services that generate positive externalities for the resident and visiting population. While Glaeser et al., (2000) claimed that urban amenities is a driver for urban development and is important in shaping the attractiveness of a place. They also suggested that amenities are influential in determining the location's allocation for others infrastructure and deciding location's destiny. A city as an entertainment machine depends on urban amenities to attract people to choose their place for living and travelling (Clark, 2000). Beside the presence of urban amenities itself, proximity to urban amenities play a major role in generating urbanization and gentrification (Glaeser et al., 2000).

The development of socio-economic infrastructure and amenities indicate the quality of life of the people of a particular area. However according to Parry et al., (2012) urban amenities are not worthwhile until they are adequately provided according to local population size and the extent of area. Partial political practices and imbalanced development policies will result in an unequal and irrational distribution of infrastructure in the region leading to the emergence of urban amenities inequality. Inequalities in accessing urban amenities means inefficiency in the distribution and allocation of facilities between areas or unequally distributed over space due to variegated spatial structure of cities (Aderamo \& Aina, 2011; Parry et al., 2012; Stevenson, 2004).

\section{CONCEPT OF URBAN AMENITIES}

Generally, half of the world's population now lives in urban area. Urbanization and urban amenities is closely related because urbanization will fuel continued growth and drawn momentum from vast expenditures to meet consumer demand such as urban 
infrastructure, amenities and housing (Yusuf, 2009). Urban amenities are specific urban facilities that contribute to residents in carrying out their urban daily life such as access to public transport, schools, grocers and professional services like clinics (Randall, 2009). Aderamo \& Aina (2011) defined urban amenities as comprising the goods, infrastructure and services required by urban society to sustain them. There are two type of urban amenities which are public and private amenities. Public amenities are those provided by governments such as parks, public clinics and school, while private amenities may include cafe, restaurants, retail or professional services (Allen, 2015).

The importance of urban amenities contribution to urban growth can be explained in terms of economic sense as well as in the context of quality of life. In terms of economic, it seems that diverse urban amenities can attract more firms and labour. The advantages provide by these amenities will generate concentration of economic and population who prefer to be in close proximity to them (Partridge et al., 2007). Quality of life and provision of urban amenities is also closely related (Chhetri et al., 2011). Accessibility and convenience of urban amenities contribute to urban life experiences (Rappaport, 2008). Access to urban amenities such electricity, sanitation, health care facilities and social amenities play a major role in determining a quality of life (Bhagat, 2011; Yasin et al., 2012). Urban amenities is therefore a crucial factor in shaping urban growth and highly influential in maintaining a socially acceptable quality of life (Glaeser et al., 2000; Parry et al., 2012).

The debate about quality of life was for a long time influenced by three philosophical approaches. The first one is characteristic of a good life influenced by religious or other system. In this context, quality of life depend neither on the subjective experience of people nor on the fulfilment of their wishes but dictated by normative rules. The second approach identified the good life based on the satisfaction of preferences. It is assumed that people select the best of quality of life based on whatever resources they have. Experience of individuals forms the basis for the third approach to quality of life and is most associated with the subjective well-being tradition in the behavioral sciences (Diener \& Suh, 1997). This approach is now used as a basis for social indicator and subjective well-being. Social indicator is an approach which involves an evaluation of quality of life by quantitative statistic and is applicable for rural and urban area (Kõrreveski, 2011). A Malaysia Well-being Index (MWI) developed by the Economic Planning Unit served as the official index investigating the wellbeing of the people in the nation. The MWI was constructed using 14 components with 68 indicators covering the economic and social wellbeing aspects for the period of 2000-2012. The components include income and distribution, transportation, working conditions, health, education, housing, environment, family life, social participation, culture and leisure, as well as public safety. It is a tool used by the government in understanding the changes and improvements in the wellbeing of the people. It also allows the government to evaluate the effectiveness of economic policies. The wellbeing of Malaysians has improved significantly over the last 12 years, according to government data compiled in the first Malaysian Wellbeing Report released yesterday. According to the numbers, the Malaysian Wellbeing Index (MWI) improved by 25.4 points over the period, or an average of $1.9 \%$ per year. The index was at 100 points in 2000 and had improved to 133.3 points in 2012. 
Muhammad Rafeq Razak, Foziah Johar \& Rabiatul Adawiyah Abd Khalil

The Impact of Iskandar Malaysia Development on Urban Amenities

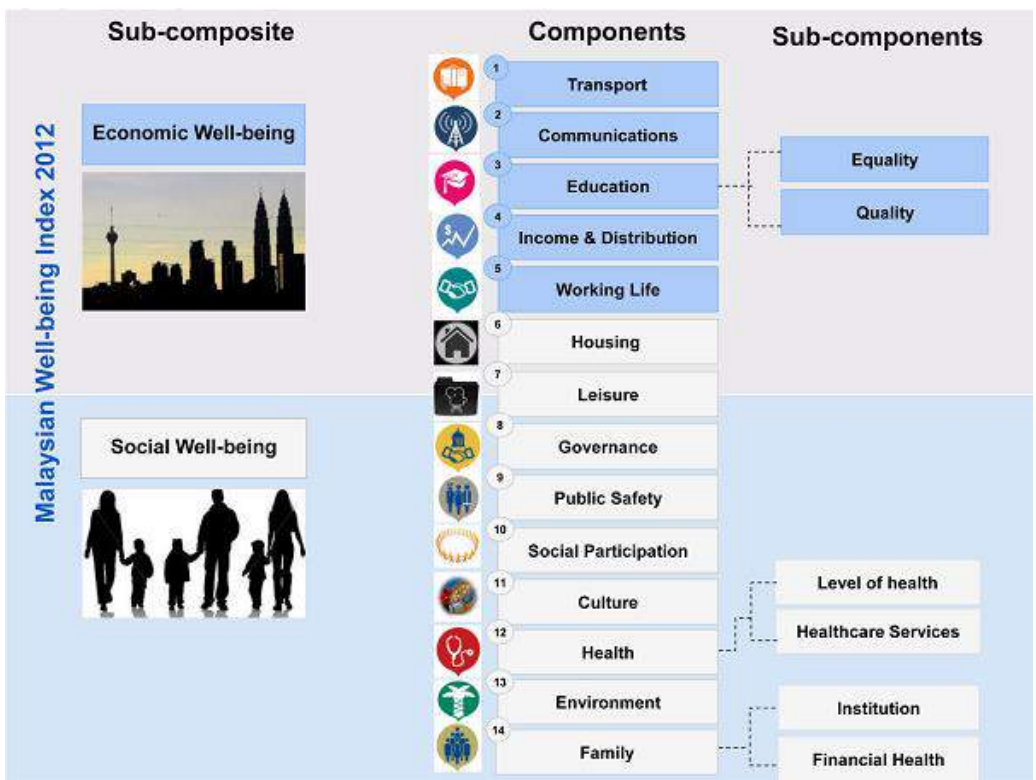

Figure 1: Malaysian Well-being Index 2012

Source: Malaysia Well-Being Report 2013

\section{DEVELOPMENT IN ISKANDAR MALAYSIA}

Iskandar Malaysia (IM) launched in 2006 lies at the heart of South East Asian and strategically located at East-West trade routes like Singapore, China and India (Foziah et al., 2006). In terms of regional contexts IM will add competitiveness to the region and will benefit significantly from the air and sea linkages within Asia-Pacific countries. According to Rizzo \& Khan, 2013, IM will receive wider impact in relation to the zones of influence of the global cities of Kuala Lumpur and Singapore. The rapid socioeconomic development in IM has brought two major transformations (Bunnell, 2002; Sabri,et al., 2012). First, the dramatic increase in urban land prices resulting in clustering of activities in particular areas. Second, the emergence of new socio-economic profile with specific preferences and lifestyle (Embong \& Macmillan, 2002). These new socioeconomic groups are middle classes that are mostly professionals, managers, and administers. Since its formation, the region has witnessed rapid development and succeeded in attracting many investors to the region. Iskandar Malaysia is estimated to have 1.35 million people or $43 \%$ of Johor's population of 3.17 million by 2025 . Some $66 \%$ of the population is of working age. As the population of the city grow, the demand for different types of public services and facilities increases (Jahan \& Oda, 1994). There are 11 Mukim in Iskandar Malaysia which covers an area of about $2216.3 \mathrm{~km} 2$. According to Jabatan Perangkaan Malaysia (2013) the current level of basic amenities, distribution and accessibility to public school and health institution in Johor was higher with $70 \%$ of population able to access those facilities within 5 kilometers. However, the influx of wealthier residents, and the clustering of business premises in certain area particularly the special economic corridor resulted in certain areas becoming exclusive, at the same 
pushing the lower income residents to areas with fewer services, amenities and institutions (Richard, 2014).

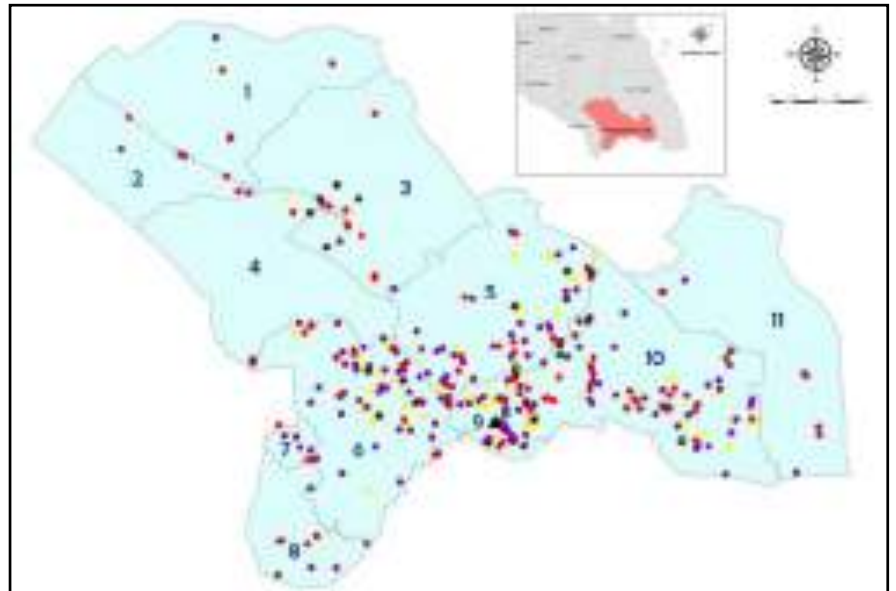

Figure 2: Distribution of health, education and safety facilities in IM

\section{METHODOLOGY}

This study focused on spatial pattern and adequacy of education, health and safety amenities distribution at Iskandar Malaysia. The data used for this study were obtained from both primary and secondary sources such as census tract report. The 2010 census data is collected to identify the number of population in each zone to facilitate analysis in the next stage. Data of selected amenities such as number of schools, clinics, hospitals and police station were provided by the Centre of Innovative Planning and Development (CIPD) UTM. The study follows the steps below:

\section{Step 1: Adequacy of Selected Facilities}

To determine the adequacy of selected amenities, the number of facilities in each Mukims was calculated in Arcgis and data capacity for each selected amenities was recorded. The capacity of each selected amenities were compared with population in each Mukim to identify areas in Iskandar Malaysia which did not have sufficient facilities.

\section{Step 2: Concentration of Selected Amenities}

The concentration of selected urban amenities distribution has been measured by Z-Score variate. Analysis of Z-score variate was used to determine spatial pattern and identify inequality in distribution. This analysis was extensively used in previous research (Aderamo \& Aina, 2011; Allen, 2015; Parry et al., 2012). The mean and standard deviation for number of amenities in each mukim was calculate to generate $\mathrm{Z}$-score result and indicate composite indicator. The $\mathrm{Z}$ score variate is calculated by the following formula: 
Muhammad Rafeq Razak, Foziah Johar \& Rabiatul Adawiyah Abd Khalil

The Impact of Iskandar Malaysia Development on Urban Amenities

$$
\begin{gathered}
Z_{1} \frac{X^{1}-\bar{X}}{S_{X}} \\
S_{X}=\sum_{i=1}\left(X_{1}-\bar{X}\right.
\end{gathered}
$$

a) Where $\mathrm{Zi}$ is the $\mathrm{Z}$-score for observation $\mathrm{i}$

b) $\mathrm{Xi}$ is the value of $\mathrm{X}$ for the ith observation

c) $\bar{X}$ is the mean of all the values of $X X$

d) $\mathrm{SX}$ is the standard deviation of the $\mathrm{X}$ values

e) $\mathrm{N}$ is the total number of observations

The study also utilised proximity analysis. Proximity analysis is able to indicate which neighbourhoods are located outside the standard distance. The standard distance to amenities established by the Federal Town and Country Planning Department in the Guidelines to Infrastructures and Public Facilities Planning is divided into 5 levels which are area within 500 meter, 1000 meter, 1500 meter, 2000 meter and 5000 meter. The neighbourhood area located within 500 meter to selected urban amenities is assumed as very accessible.

\section{ISKANDAR MALAYSIA}

Nowadays, due to extensive development, a lot of existing natural and agricultural land cover have been converted into anthropogenic land cover. The city-region has also witnessed widespread urban renewal and new urban/suburban projects which resulted in distinct physical and socio-economic changes. Previous land use in Nusajaya for instance, was largely agriculture and green field occupied by villages and fishing communities. Since the implementation of IM in 2006, almost half of land use in Nusajaya can now be categorized as commercial, institutional and public facilities. These include such uses as a private university, hospitals, retail and theme parks. This changes of land use will soon change the image of Nusajaya in term of cultural and ethnic background, personality, attitudes, motivation, income, age, length of stay, lifestyle, social class and socioeconomic group (Nasongkhla \& Sintusingha, 2012; Suthasupa, 2011) 


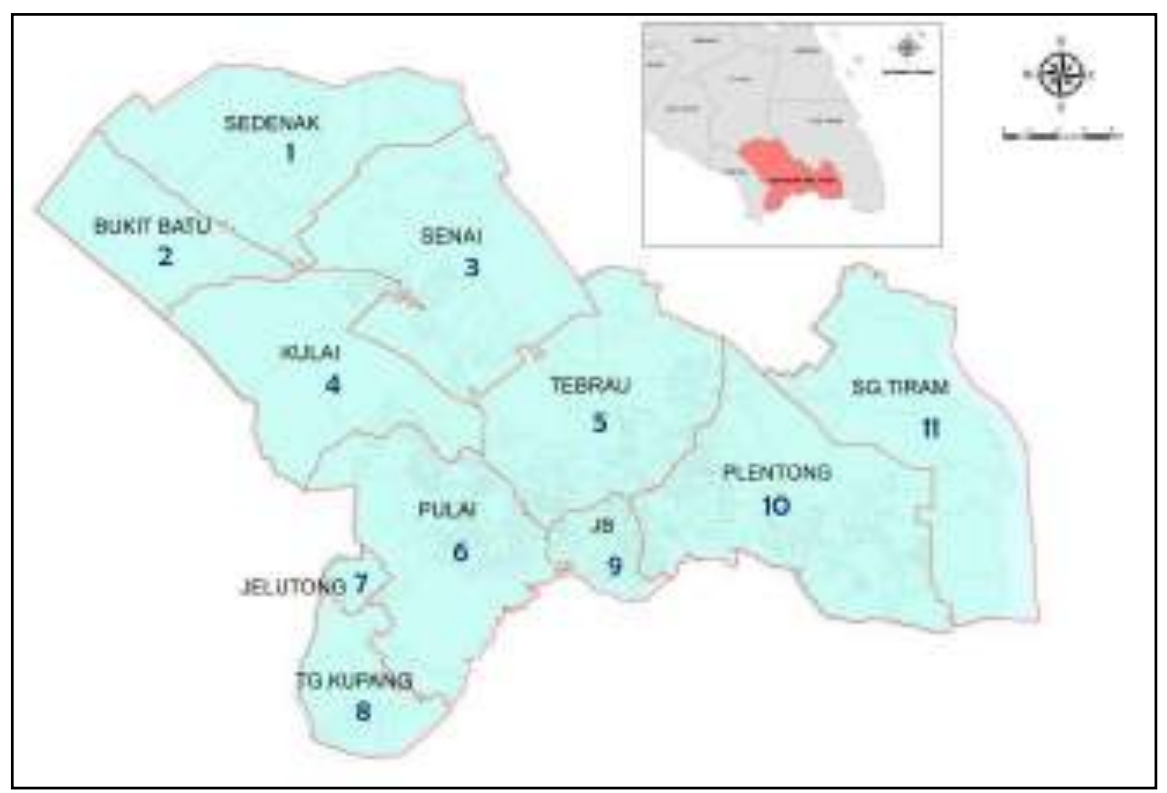

Figure 3: Study Area

\section{RESULT AND DISCUSSION}

\section{Distribution of selected urban amenities}

Table 5.1 shows the number of population, schools, police station and health amenities in each mukims, within Iskandar Malaysia. It shows that Mukim Plentong has the highest number of facilities with 89 schools, 14 healthcare and 7 police stations. This is followed by Mukim Pulai with 60 schools, 9 healthcare and 7 police stations; Mukim Tebrau (42 schools, 11 healthcare, 5 police stations) and Mukim Bandar Johor Bahru (41 schools, 5 healthcare, 3 police station). The other mukims recorded lesser numbers of amenities for education, health, safety and security. 
Muhammad Rafeq Razak, Foziah Johar \& Rabiatul Adawiyah Abd Khalil

The Impact of Iskandar Malaysia Development on Urban Amenities

Table 1: Distribution of Education, Health and Safety Amenities at Iskandar Malaysia

\begin{tabular}{|c|c|c|c|c|c|c|c|c|}
\hline \multirow[b]{2}{*}{ Mukim } & \multirow[b]{2}{*}{ Population } & \multicolumn{2}{|c|}{ Education } & \multicolumn{2}{|c|}{ Health } & \multicolumn{2}{|c|}{ Safety and Security } & \multirow{2}{*}{ Total } \\
\hline & & Primary & Secondary & Clinics & Hospital & $\begin{array}{l}\text { Police } \\
\text { Station }\end{array}$ & $\begin{array}{l}\text { Community } \\
\text { Police Post }\end{array}$ & \\
\hline Pulai & 360642 & 42 & 18 & 9 & $\mathbf{0}$ & 7 & $\mathbf{0}$ & 76 \\
\hline Plentong & 494152 & 56 & 33 & 14 & $\mathbf{0}$ & 6 & 1 & 110 \\
\hline Tebrau & 316327 & 29 & 13 & 9 & 2 & 4 & 1 & 58 \\
\hline $\begin{array}{l}\text { Bandar Johor } \\
\text { Bahru }\end{array}$ & 124096 & 25 & 16 & 4 & 1 & 3 & $\mathbf{0}$ & 49 \\
\hline Kulai & 93784 & 5 & 1 & 3 & 0 & 2 & 1 & 12 \\
\hline Sedenak & 17212 & 2 & 0 & 4 & 0 & 0 & 0 & 6 \\
\hline Senai & 120312 & 3 & 2 & 6 & 1 & $\mathbf{0}$ & 3 & 15 \\
\hline Sungai Tiram & 13348 & 5 & 0 & 3 & 0 & 0 & 0 & 8 \\
\hline $\begin{array}{l}\text { Tanjung } \\
\text { Kupang }\end{array}$ & 10972 & 5 & 2 & 2 & 0 & 0 & 0 & 9 \\
\hline Jelutong & 14651 & 4 & 1 & 1 & 0 & 0 & 0 & 6 \\
\hline Bukit Batu & 13986 & 2 & 0 & 3 & 0 & 0 & 0 & 5 \\
\hline
\end{tabular}

Source: 1. Department of Statistic Malaysia, 2. Centre of Planning Development (CIPD UTM)

The provision of education, health and security amenities depend on population size in a particular area. However, educational facilities provided in Mukim Senai are not sufficient to cater for its population which indicate an inequality in distribution when compared to Mukim Bandar Johor Bahru which has almost similiar population range with Mukim Senai. In term of health amenities, the distribution of these amenities in Iskandar Malaysia was adequate and corresponds to population size. There are 4 hospitals within Iskandar Malaysia that have a capacity to accommodate the current population. In terms of safety and security amenities, Mukim Senai, Sedenak, Sg, Tiram, Tanjung Kupang, Jelutong and Bukit Batu do not have a police station although the population in those mukim meet the requirement for the provision of a police station.

\section{Spatial variation of urban amenities distribution}

The inequalities and spatial distribution of urban amenities in Iskandar Malaysia was analyse by using Z-score variate. This Z-score variate approach has been used frequently in previous geographic research (Aderamo \& Aina, 2011; Parry et al., 2012). Table 5.2 shows the standardized score of spatial pattern of three urban amenities concentration in Iskandar Malaysia which is education, health and safety. 
Table 2: Standardized score for urban amenities distribution

\begin{tabular}{lrrrrrrr}
\hline \multirow{2}{*}{ Mukim } & \multicolumn{2}{c}{ Education } & \multicolumn{2}{c}{ Health } & \multicolumn{2}{c}{ Safety and Security } & Composite \\
\cline { 2 - 6 } & Primary & Secondary & Clinics & Hospital & $\begin{array}{c}\text { Police } \\
\text { Station }\end{array}$ & $\begin{array}{c}\text { Community } \\
\text { Police Post }\end{array}$ \\
\hline Pulai & -0.4788 & -0.02517 & -0.89049 & -0.6067 & $\mathbf{1 . 1 8 5 3 5}$ & -0.50269 & -1.3185 \\
Plentong & -0.50297 & $\mathbf{0 . 2 7 5 7 8}$ & -0.85129 & -0.6067 & $\mathbf{0 . 4 1 9 9 5}$ & -0.22826 & -1.49349 \\
Tebrau & -0.67001 & -0.18242 & -0.84989 & 1.25272 & $\mathbf{0 . 4 7 2 9 5}$ & -0.0741 & -0.05075 \\
Bandar Johor & $\mathbf{0 . 1 7 7}$ & $\mathbf{1 . 3 8 4 5 1}$ & -0.80597 & $\mathbf{1 . 7 6 3 1 9}$ & $\mathbf{1 . 6 8 7 1 2}$ & -0.50269 & $\mathbf{3 . 7 0 3 1 6}$ \\
Bahru & -0.966 & -0.72532 & -0.80882 & -0.6067 & $\mathbf{1 . 3 8 7 0 5}$ & $\mathbf{0 . 9 4 3 0 8}$ & -0.77671 \\
Kulai & -0.48083 & -0.91555 & $\mathbf{1 . 5 1 8 4 6}$ & -0.6067 & -0.85874 & -0.50269 & -1.84605 \\
Sedenak & -1.18494 & -0.619 & -0.60116 & $\mathbf{1 . 8 3 7 7 1}$ & -0.85874 & $\mathbf{2 . 8 7 8 1 9}$ & $\mathbf{1 . 4 5 2 0 6}$ \\
Senai & $\mathbf{1 . 5 1 2 7 8}$ & -0.91555 & $\mathbf{1 . 4 2 9 7}$ & -0.6067 & -0.85874 & -0.50269 & $\mathbf{0 . 0 5 8 8}$ \\
Sungai Tiram & $\mathbf{2 . 1 3 8 6 6}$ & $\mathbf{2 . 3 3 6 2 3}$ & $\mathbf{0 . 9 3 6 5}$ & -0.6067 & -0.85874 & -0.50269 & $\mathbf{3 . 4 4 3 2 6}$ \\
Tanjung Kupang & $\mathbf{0 . 7 2 9 1 4}$ & $\mathbf{0 . 3 0 2 0 6}$ & -0.38767 & -0.6067 & -0.85874 & -0.50269 & -1.3246 \\
Jelutong & -0.27403 & -0.91555 & $\mathbf{1 . 3 1 0 6 4}$ & -0.6067 & -0.85874 & -0.50269 & -1.84707 \\
Bukit Batu & & & & & & &
\end{tabular}

Source: Author

Bahru and Jelutong due to the uneven population compare to others mukim Mukim Johor Bahru has been recognized as city centre for Johor and most of urban amenities have already existed before the implementation of Iskandar Malaysia. Meanwhile, Mukim Senai recorded as less served of education facilities due to its function as industrial area. In term of health facilities, clinics in Iskandar Malaysia were highly concentrated at Mukim Sedenak, Bukit Batu, Tanjung Kupang and Sg.Tiram. Mukim Pulai and Plentong have less concentration of clinics although the numbers of population in both mukim are higher. However, the less provision of clinics in others mukim is not an issue since there are four hospitals has been provided in Mukim Johor Bahru, Tebrau and Senai to meet the requirement of current population for health amenities.

The Malaysia crime index 2013 was higher as much as $74.5 \%$ which covered about 111,000 reported cases. Johor Bahru indicates a similar trend where the crime index has increased and ranked as fourth city that has highest crime rates. Despite the state government has provided 16 Community Police Post across Iskandar Malaysia starting from 2010 to prevent crime although crime index does not show any decline (refer figure 4). The higher crime index indicated the level of security and safety still lower. Therefore the distance and location of police station or community police post should be revised to ensure those services are adequate. 
Muhammad Rafeq Razak, Foziah Johar \& Rabiatul Adawiyah Abd Khalil

The Impact of Iskandar Malaysia Development on Urban Amenities

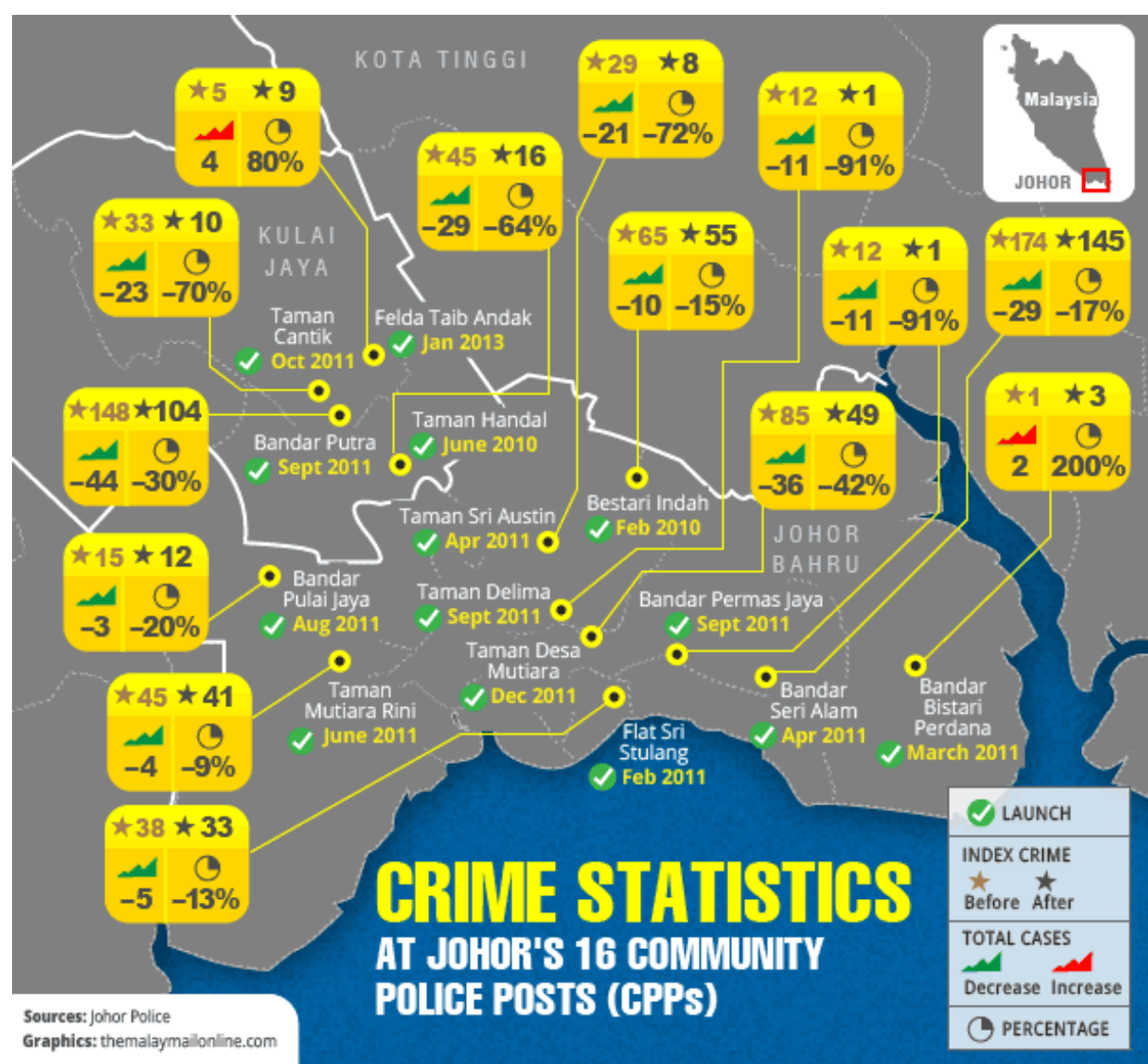

Figure 4: Location of Community Police Post and Population in Iskandar Malaysia

The safety and security amenities pattern in Iskandar Malaysia is much focus to the area with higher population such as Mukim Pulai, Plentong, Johor Bahru, Tebrau and Kulai. The provision of this amenities in others mukim should be considered since there are area which have no police station although the population is higher such in Senai and Sedenak. Based on composite indicator for urban amenities, the provision of social amenities in Iskandar Malaysia is best served in Johor Bahru, Senai, Tanjung Kupang and Sg Tiram, followed by Kulai and Tebrau with mediate level of amenities provision. Meanwhile, Pulai, Plentong, Jelutong, Sedenak and Bukit Batu have the worst level of urban amenities distribution.

\section{Proximity of amenities to neighbourhood in Iskandar Malaysia}

The results of proximity analysis show that $96 \%$ of residents in Iskandar Malaysia have access to primary schools within 5 kilometres. However, only $17 \%$ of the neighbourhood areas meet the planning standard of 500 meters and $28 \%$ within 1 kilometre. The distance of more than 1 kilometre will increase the travel distance among residents which at the same time increase the traffic volume. 

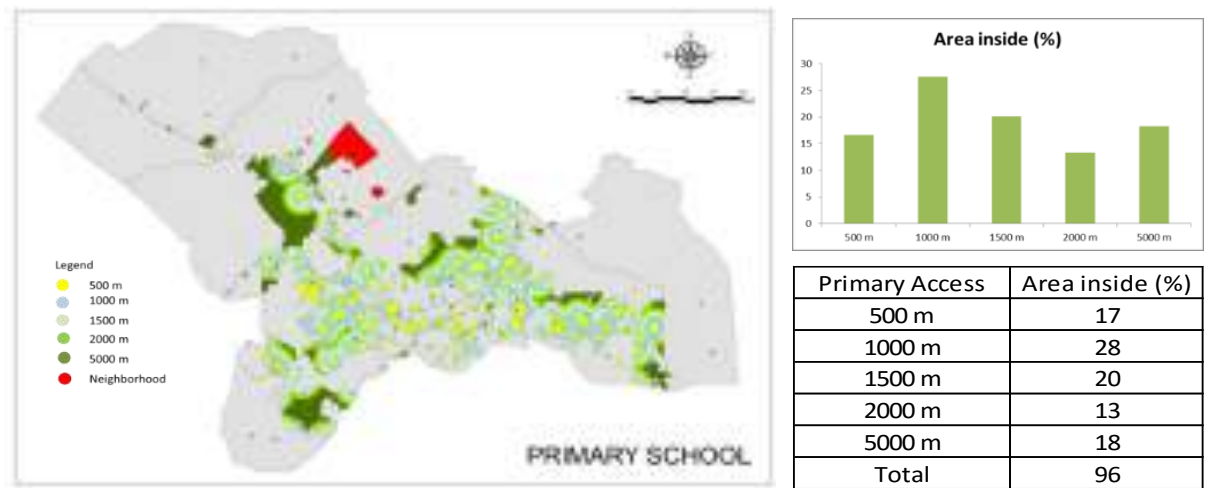

Figure 5: Proximity to Primary School

For secondary schools, $83 \%$ of the residents stay within 5 kilometers. The remaining $17 \%$ residents located in Mukim Senai and Pulai need to travel more to access the secondary school. The results indicate the potential area especially at Mukim Senai and Pulai to be provided with secondary schools to cater the demand for future. The proximity to health facilities shows $95 \%$ of resident in neighbourhood area have access to this amenities within 5 kilometres. However, only $4 \%$ have access within 500 meter which indicates that the health amenities are located at non-strategic area.
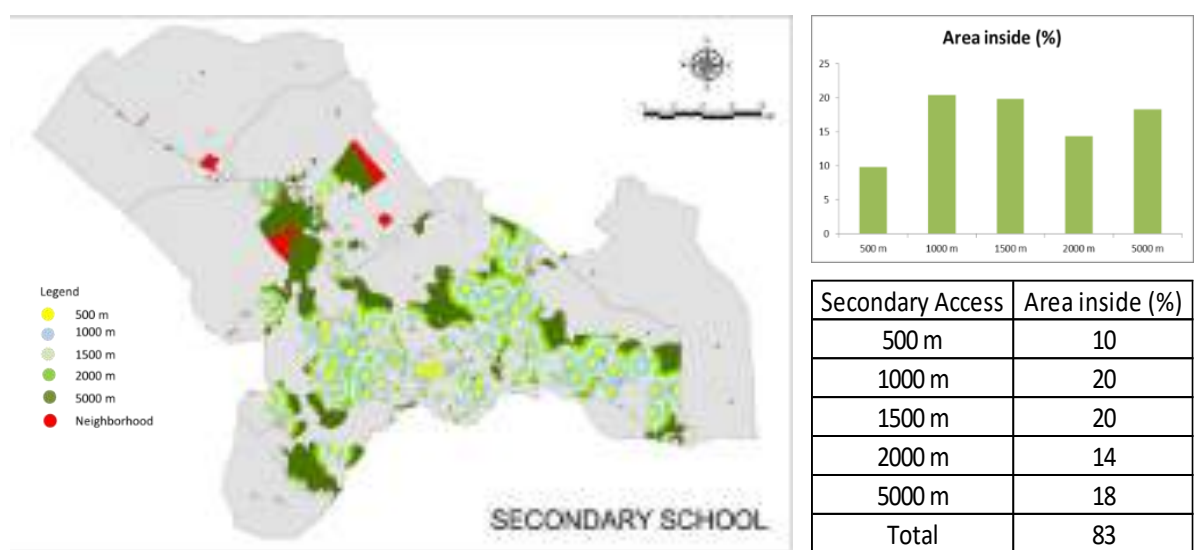

\begin{tabular}{|l|l|}
\hline Secondary Access & Area inside (\%) \\
\hline $500 \mathrm{~m}$ &
\end{tabular}

\begin{tabular}{|c|c|}
\hline $500 \mathrm{~m}$ & 10 \\
\hline $1000 \mathrm{~m}$ & 20 \\
\hline $1500 \mathrm{~m}$ & 20 \\
\hline $2000 \mathrm{~m}$ & 14 \\
\hline $5000 \mathrm{~m}$ & 18 \\
\hline Total & 83 \\
\hline
\end{tabular}

Figure 6: Proximity to Secondary School 
Muhammad Rafeq Razak, Foziah Johar \& Rabiatul Adawiyah Abd Khalil

The Impact of Iskandar Malaysia Development on Urban Amenities
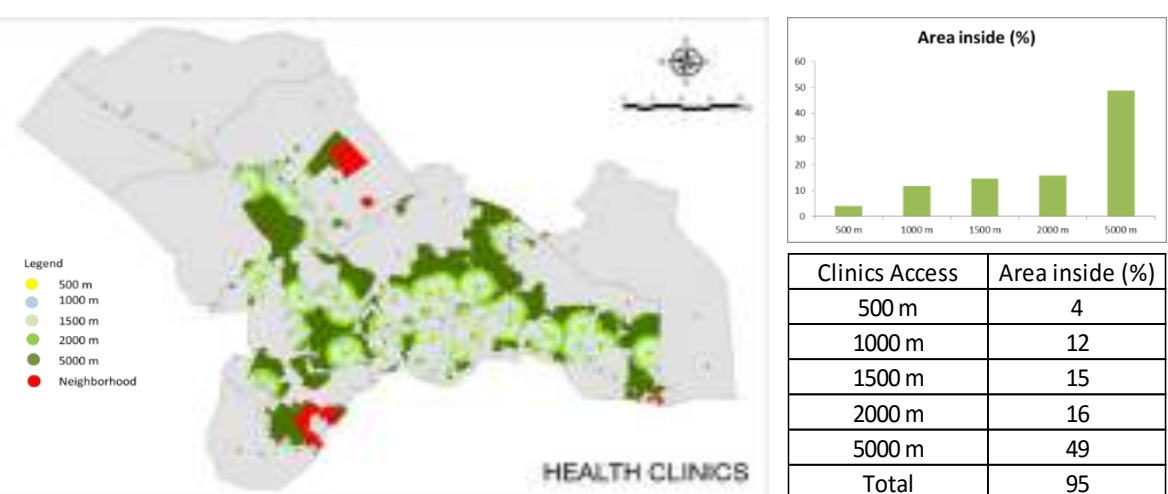

Figure 7: Proximity to Healthcare Amenities

In terms of safety and security, the proximity to police station recorded $80 \%$ of residents have access within 5 kilometer. The planning standard for distance to police station is 1 kilometer and only $9 \%$ have access within that area. Overall, the proximity to selected urban amenities was higher for current situation. However any areas such as Mukim Johor Bahru, Plentong, Kulai and Tebrau whill have to be considered for future population increase.
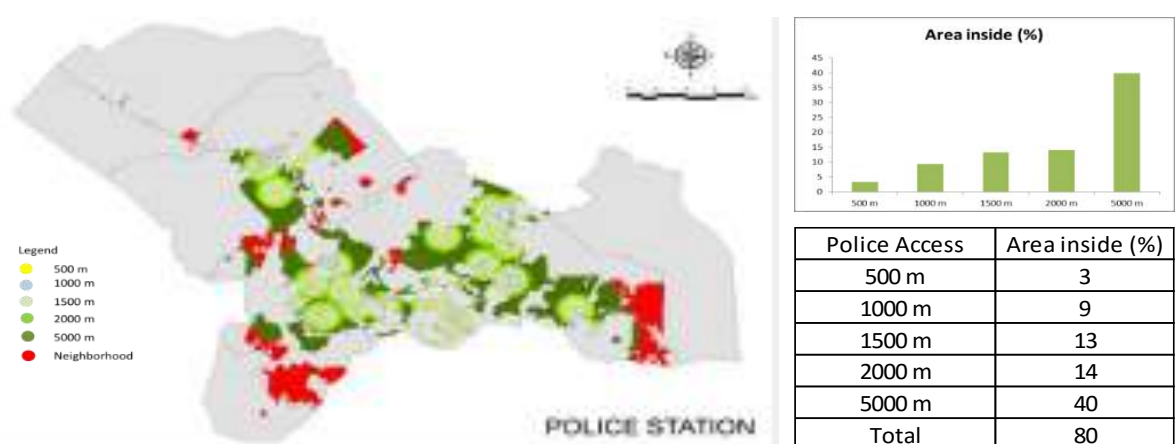

Figure 8: Proximity to Safety and Security Amenities

\section{CONCLUSION}

Public facilities such as schools, health centres, police stations are generally not uniformly distributed. This is common in developing countries where apart from uneven population distribution, many other extraneous factors such as political consideration go into locational decisions. However, consideration for the well-being of the people should be a paramount factor in the provision of facilities so that the people will have a sense of belonging and the orientation of the people towards the use of these facilities will also change positively. 


\section{ACKNOWLEDGMENTS}

We would like to acknowledge the support by the Grant University Project (R.J130000.7821.4L124) from Universiti Teknologi Malaysia.

\section{REFERENCES}

Aderamo, A. J., \& Aina, O. A. (2011). Spatial Inequalities in Accessibility to Social Amenities in Developing Countries : a Case from Nigeria, 5(6), 316-322.

Allen, N. (2015). Understanding the Importance of Urban Amenities: A Case Study from Auckland. Buildings, 5, 85-99. doi:10.3390/buildings5010085

Bhagat R.B. (2011). Access to Basic Amenities in Urban Areas by Size class of Cities and Towns in India., 31(1), 1-13.

Bunnell, T. I. M. (2002). Cities for Nations ? Examining the City - Nation-State Relation in Information Age Malaysia *. International Journal of Urban and Regional Research, 26(2), 284-298.

Butler, T. I. M., \& Robson, G. (2003). Plotting the Middle Classes: Gentrification and Circuits of Education in London. Housing Studies, 18(December 2014), 5-28. doi:10.1080/0267303032000076812

Chhetri, P., Stimson, R., \& Western, J. (2011). Investigating Quality of Urban Life, 45, 405-434. doi:10.1007/978-94-007-1742-8

Clark, T. N. (2004). The City as an Entertainment Machine (p. 336). Retrieved from http://books.emeraldinsight.com/display.asp?K=9780762310609\&sf1=series\& st $1=$ Research in Urban Policy\&sort=sort_date/d\&cur=EUR\&m $=4 \& d c=9$

Diener, E. D., \& Suh, E. (1997). Measuring quality of life: economic, social, and subjective indicators. Social Indicators Research, 40, 189-216. doi:10.1023/A:1006859511756

Embong, A. R., \& Macmillan, P. (2002). State-led Modernization and the New Middle Class in Malaysia. doi:10.1057/9781403914286preview

Glaeser, E. L., Kolko, J., \& Saiz, A. (2000). H i e r. Harvard Institute of Economic Research, 1901(June 2000), 1-32.

Hogan, T., Bunnell, T., Pow, C.-P., Permanasari, E., \& Morshidi, S. (2012). Asian urbanisms and the privatization of cities. Cities, 29(1), 59-63. doi:10.1016/j.cities.2011.01.001

Jabatan Perangkaan Malaysia. (2010). Population Distribution And Basic Demographic Characteristics.

Jabatan Perangkaan Malaysia. (2013). Laporan Penyiasatan Pendapatan Isi Rumah Dan Kemudahan Asas 2012. Sumber Statistik Rasmi Malaysia. Retrieved from http://www.statistics.gov.my/portal/index.php?option=com_content\&view=arti cle\&id=1640\&Itemid=111\&lang=bm

Jahan, S., \& Oda, T. (1996). Distribution of Public Facilities in Dhaka, Bangladesh : A Spatial Analysis. The Bangladesh Urban Studies.

Johar, F., \& Adawiyah, R. K. (2014). Gentrification and Its Socio-Economic Implications in Iskandar Malaysia, (IASUR Conference 2014).

Kõrreveski, K. (2011). Measuring Well-Being and Quality of Life Using Oecd, 38-44.

Machado, A. F., Simões, R. F., \& Diniz, S. C. (2013). Urban Amenities and the Development of Creative Clusters: The Case of Brazil. Current Urban Studies, 01(04), 92-101. doi:10.4236/cus.2013.14010 
Muhammad Rafeq Razak, Foziah Johar \& Rabiatul Adawiyah Abd Khalil

The Impact of Iskandar Malaysia Development on Urban Amenities

Moore, M., Gould, P., \& Keary, B. S. (2003). Global urbanization and impact on health. International Journal of Hygiene and Environmental Health, 206, 269-278. doi:10.1078/1438-4639-00223

Morshidi, S. (2000). Globalising Kuala Lumpur and the Strategic Role of the Producer Services Sector. Urban Studies, 37(12), 2217-2240. doi:10.1080/00420980020002788

Nasongkhla, S., \& Sintusingha, S. (2012). Social Production of Space in Johor Bahru. Urban Studies, 50(9), 1836-1853. doi:10.1177/0042098012465907

Newton, P. (2001). Urban Indicator for Managing Cities. Asian Development Bank $A D B$ ) (pp. 1-8).

Noraniza, Y., Azlizan, T., \& Yusuf, P. (2011). Impak Pembangunan Infrastruktur ke atas Pembangunan Komuniti Penduduk di Daerah Pendang dan Kubang Pasu , Kedah Darul Aman , Malaysia Infrastructure Development Impact on Inhabitant Community Development at Kubang Pasu and Pendang District , Kedah Darul A, 7, 16-35.

Parry, J. A., Ganaie, S. A., Nengroo, Z. A., \& Bhat, M. S. (2012). Spatial Analysis on the provision of Urban Amenities and their Deficiencies - A Case Study of Srinagar City , Jammu and Kashmir, India (Vol. 2).

Partridge, M., Olfert, M. R., \& Alasia, A. (2007). Canadian Cities As Regional Engines of Growth: Agglomeration and Amenities. The Canadian Journal of Economics / Revue Canadienne d'Economique, 40(1), 39-68. doi:10.2307/4620596

Randall, T. a. (2009). Preferences of suburban residents in Thunder Bay, Ontario towards neighbourhood intensification and rediversification. Canadian Journal of Urban Research, 17, 28-56.

Rappaport, J. (2008). Consumption Amenities and City Population Density. Regional Science and Urban Economics, 38(6, Nov 2008), 533-552.

Richard, E. A. (2014). The Implications Of The Theory Of Gentrification For Masakare Settlement. Adamawa: Federal University of Technology.

Rizzo, A., \& Khan, S. (2013). Johor Bahru's Response to Transnational and National Influences in The Emerging Straits Mega-City Region. Habitat International, 40(2013), 154-162. doi:10.1016/j.habitatint.2013.03.003

Sabri, Soheil M. Ludin, Ahmad Nazri Johar, F. (2012). Gentrification and local strategies to mitigate displacement: case of Kuala Lumpur, Malaysia. Malaysian Townplan Journal, 1-20. Retrieved from http://eprints.utm.my/30490/

Stevenson, D. (2004). " Civic Gold" Rush : Cultural Planning and the Politics of the Third Way Deborah Stevenson Deputy Director, Cultural Industries and Practices Research Centre, University of Newcastle, 1-2.

Suthasupa, S. (2011). The Portrayal of a City' s Image by Young People. Journal of ASIAN Behavioural Studies, 1(2), 57-68.

Yasin, G., Sattar, S., \& Faiz, F. A. (2012). Rapid urbanization as a source of social and ecological decay: A case of Multan city, Pakistan. Asian Social Science, 8(4), 180-189. doi:10.5539/ass.v8n4p180

Yusuf, S. (2009). Off to the City Focus: Economy. In China Business Reveiw (May-June 2., p. 13). China Business Review. 